\title{
Commentary Toward protein-energy goal-oriented therapy?
}

\author{
Pierre Singer
}

\begin{abstract}
Institute for Nutrition Research, General Intensive Care Department, Rabin Medical Center, Sackler School of Medicine, Tel Aviv University, Kaplan Street, Petah Tikua 49100, Tel Aviv, Israel
\end{abstract}

Corresponding author: Pierre Singer, psinger@clalit.org.il

Published: 1 October 2009

This article is online at http://ccforum.com/content/13/5/188

Critical Care 2009, 13:188 (doi:10.1186/cc8042)

(c) 2009 BioMed Central Ltd

See related research by Strack van Schijndel et al., http://ccforum.com/content/13/4/R132

\begin{abstract}
Protein calorie malnutrition is a concern in critically ill patients. Prospective studies to define the ideal calorie/protein intake to administer not only to meet requirements but also to change outcome are lacking. Strack van Schijndel and colleagues have observed an improvement in survival when patients reach the calorie target according to indirect calorimetry and a protein intake of greater than $1.2 \mathrm{~g} / \mathrm{kg}$ per day. Their prospective observational study sheds new light on this field.
\end{abstract}

\section{Introduction}

Using energy targeting and adequate protein calorie supply, Strack van Schijndel and colleagues [1] have reported an improvement in the outcome of critically ill patients. Early enteral feeding has become the first line for nutritional support in critically ill patients [2]. However, reaching the calorie target remains difficult $[3,4]$. Additionally, there is still extensive debate on the amount of calories and protein to prescribe to severely ill patients. Guidelines of the European Society of Clinical Nutrition and Metabolism recommend that intensive care unit (ICU) patients be fed because starvation or underfeeding is associated with increased morbidity and mortality [2-4] and that all patients who are not expected to be on normal nutrition within 3 days receive parenteral nutrition (PN) within 24 to 48 hours if enteral nutrition (EN) is contraindicated or if they cannot tolerate EN. In patients who are not fed sufficiently by the enteral route, the deficit should be supplemented by the parenteral route [5] (grade C). Overfeeding should be avoided.

Guidelines of the American Society for Parenteral and Enteral Nutrition and the Society of Critical Care Medicine [6] recommend that, if energy requirements $(100 \%$ of target goal calories) are unable to be met after 7 to 10 days by the enteral route alone, the physician consider initiating supplemental PN (grade E). Initiating supplemental PN prior to this
7- to 10-day period in a patient already receiving $\mathrm{PN}$ may not improve outcome and may be detrimental (grade $\mathrm{C}$ ).

These conflicting recommendations result from the lack of answers, based on solid scientific evidence, to the following questions: Should calorie administration be guided by indirect calorimetry to reach a better outcome? How do different levels of feeding affect outcome (mortality and lengths of stay in the ICU or in the hospital), and should feeding be tailored to the estimated requirements of the individual or should a limited number of standard regimens be sufficient? What are the consequences of a cumulative calorie deficit?

Strack van Schijndel and colleagues [1] have answered some of these questions by using observations collected during nutritional support guided by good clinical practice. They use Harris-Benedict equations multiplied by 1.3 at admission to define a calorie target, and after 3 to 5 days, they are able to measure energy expenditure. Then they try to administer energy and protein according to a measured energy expenditure multiplied by 1.1 to cover activity expenses and more than $1.2 \mathrm{~g} / \mathrm{kg}$ per day of protein. Should calorie administration be guided by indirect calorimetry? Yes, since doing so improves mortality.

\section{The available evidence is poor}

In the available literature, the evidence is difficult to collect since the common practice is to underfeed ICU patients $[7,8]$. When McCowen and colleagues [9] planned to compare normocaloric with hypocaloric regimens, both groups were underfed (14 versus $18 \mathrm{kcal} / \mathrm{kg}$ per day). In addition, two more parameters interfere with the analysis of the data: the nutritional status of the patient at admission and the cumulative energy balance, which is a direct consequence of the length of stay of the patient. Two recent papers have shown that underfed patients and severely obese patients

$\mathrm{EN}=$ enteral nutrition; $\mathrm{ICU}=$ intensive care unit; $\mathrm{PN}=$ parenteral nutrition. 
have a higher independent risk of mortality [10,11], and in most of the studies, the patients are not stratified according to their nutritional status. Second, the cumulative energy balance becomes an important prognostic factor if the ICU stay is longer than 5 to 7 days and if the balance exceeds $10,000 \mathrm{kcal}$. Bartlett and colleagues [12] have already demonstrated that this limit should not be exceeded. Villet and colleagues [3] and Dvir and colleagues [4] showed the importance of cumulative energy balance by using a computerized information system that allowed an easy way to calculate the negative balance. Using software that evaluates energy balance in a fast and easy way is becoming an important part of the nutritional assessment of the critically ill patient.

\section{Gender, protein, and outcome}

This is not the first time that gender has influenced outcome in the multivariate analysis of critically ill patients $[13,14]$. The explanation provided by Strack van Schijndel and colleagues is that women have a lower body weight and thus their energy requirements are not as great. In addition, females reached nutritional goals more often than males (33.3\% versus $17.7 \%)$. Gender impacts upon the inflammatory and metabolic response in pediatric burn patients [13] and outcome in nosocomial pneumonia [14], this time in favouring males. This study [1] was not planned to answer this question, and there are many confounders in the evaluation of gender impact on intensive care survival when nutrition is adequate.

Forse and colleagues [15] have suggested that the administration of enough calories should be associated with enough protein. They showed that high nitrogen intake markedly increased plasma insulin and glucagon concentrations but reduced glycerol, fatty acid, and 3-hydroxybutyrate concentrations, independently of glucose intake. This may explain the more efficient utilization of calories at higher levels of nitrogen intake. The effect of gender on calorie utilization has not been investigated. Prospective randomized studies administering calories according to indirect calorimetry and protein at different levels will define more precisely the true role of protein in the critically ill.

\section{Competing interests}

The author declares that they have no competing interests.

\section{References}

1. Strack van Schijndel RJ, Weijs PJ, Koopmans RH, Sauerwein HP, Beishuizen A, Girbes AR: Optimal nutrition during the period of mechanical ventilation decreases mortality in critically ill, long-term acute female patients: a prospective observational cohort study. Crit Care 2009, 13:R132.

2. Kreymann KG, Berger MM, Deutz NE, Hiesmayr M, Jolliet $P$, Kazandjiev G, Nitenberg G, van den Berghe G, Wernerman J; DGEM (German Society for Nutritional Medicine), Ebner C, Hartl W, Heymann C, Spies C; ESPEN (European Society for Parenteral and Enteral Nutrition): ESPEN guidelines on enteral nutrition: intensive care. Clin Nutr 2006, 25:210-223.

3. Villet S, Chiolero RL, Bollmann MD, Revelly JP, Cayeux R N MC Delarue J, Berger MM: Negative impact of hypocaloric feeding and energy balance on clinical outcome in ICU patients. Clin
Nutr 2005, 24:502-509.

4. Dvir D, Cohen J, Singer P: Computerized energy balance and complications in critically ill patients: an observational study. Clin Nutr 2006, 25:37-44.

5. Singer $P$, Berger MM, Van den Berghe $G$, Biolo $G$, Calder $P$, Forbes A, Griffiths R, Kreyman G, Leverve X, Pichard C: ESPEN guidelines for parenteral nutrition: intensive care. Clin Nutr 2009, 28:387-400.

6. McClave SA, Martindale RG, Vanek VW, McCarthy M, Roberts P, Taylor B, Ochoa JB, Napolitano L, Cresci G; A.S.P.E.N. Board of Directors; American College of Critical Care Medicine; Society of Critical Care Medicine: Guidelines for the provision and assessment of nutrition support therapy in the adult critically ill patient: Society of Critical Care Medicine (SCCM) and American Society for Parenteral and Enteral Nutrition (ASPEN). JPEN J Parenter Enteral Nutr 2009, 33:277-316.

7. Martin CM, Doig GS, Heyland DK, Morrison T, Sibbald WJ: Multicentre, cluster randomized clinical trial of algorithms for critical-care enteral and parenteral therapy (ACCEPT). CMAJ 2004, 170:197-204.

8. Doig GS, Simpson F, Finfer S, Delaney A, Mitchell I, Gobb G: Effects of evidence based feeding guidelines on mortality of critically ill patients. A cluster randomized controlled trial. JAMA 2008, 300:2731-2741.

9. McCowen KC, Friel C, Sternberg J, Chan S, Forse RA, Burke PA Bistrian BR: Hypocaloric total parenteral nutrition: effectiveness in prevention of hyperglycemia and infectious complications: a randomized clinical trial. Crit Care Med 2000, 28: 3606-3611.

10. Choban PS, Burge JC, Scales D, Flancbaum L: Hypoenergetic nutrition support in hospitalized obese patients: a simplified method for clinical application. Am J Clin Nutr 1997, 66:546550.

11. Dickerson RN: Hypocaloric feeding of obese patients in the intensive care unit. Curr Opin Clin Nutr Metab Care 2005, 8: 189-196.

12. Bartlett RH, Dechert RE, Mault JR, Ferguson SK, Kaiser AM, Erlandson EE: Measurement of metabolism in multiple organ failure. Surgery 1982, 92:771-779.

13. Jeschke MG, Mlcak RP, Finnerty CC, Norbury WB, Przkora R, Kulp GA, Gauglitz GG, Zhang XJ, Herndon DN: Gender differences in pediatric burn patients: does it make a difference? Ann Surg 2008, 248:126-36.

14. Combes A, Luyt CE, Trouillet JL, Nieszkowska A, Chastre J: Gender impact on the outcomes of critically ill patients with nosocomial infections. Crit Care Med 2009, 37:2506-2511.

15. Forse RA, Elwyn DH, Askanazi J, lles M, Schwarz Y, Kinney JM: Effects of glucose on nitrogen balance during high nitrogen intake in malnourished patients. Clin Sci (Lond) 1990, 78:273281. 